\title{
THE VARIABILITY OF PROTEINURIA IN THE HYPERTENSIVE COMPLICATIONS OF PREGNANCY
}

\author{
By LEON C. CHESLEY \\ (From the Department of Biochemistry, Margaret Hague Maternity Hospital, Jersey City)
}

(Received for publication July 10, 1939)

Proteinuria in eclampsia was first described by Lever (1) in 1843, and since that time has been interpreted by many writers as a sign of a renal lesion underlying the toxemias of pregnancy. In late years however, arteriolar, and possibly capillary, spasms have been advanced as an explanation for the leakage of protein through the glomerular capillaries, not only in the toxemias of pregnancy but also in acute glomerulonephritis and in essential hypertension (Volhard (2), Irving (3), Eastman (4)). In a recent paper Chesley, Markowitz and Wetchler (5) have shown that even very transitory vasospasm does result in proteinuria.

Perhaps a study of the variability of protein leakage into the urine, during successive periods, would yield data pointing toward one of the other alternative interpretations of proteinuria in toxemia. In the presence of a diffuse renal lesion, one might expect a nearly constant leakage of protein. On the other hand, if the proteinuria were caused by vascular constriction, the protein leakage might fluctuate from moment to moment, waxing and waning with more and less intense vascular spasms. If the periods of observation be too long, it is conceivable that the proteinuria might " average out." As the first approach to the problem, the urine output has been collected at hourly intervals. The plasma clearance of endogenous creatinine has been determined as a rough measure of the glomerular filtration, and compared with the protein excretion. This comparison perhaps enables one to calculate the approximate concentration of protein in the glomerular filtrate (see below); in other words, the calculation gives the protein leakage through the glomerular capillaries.

\section{MATERIAL AND METHODS}

Patients were selected in whom the differential diagnosis could be made between preeclamptic toxemia and Bright's disease complicated by pregnancy. The criteria for preeclamptic toxemia in- clude a rapid and excessive gain in weight, hypertension, proteinuria, and edema, all appearing for the first time late in the pregnancy-usually in the order mentioned-and disappearing rapidly following delivery. Renal function is normal insofar as it is shown by the urea clearance. Nearly all patients used were primigravidae. The criteria for Bright's disease are hypertension, proteinuria, edema, hematuria, and persistently lowered urea clearance. In nearly all cases used in this study, some of these signs were known to have existed either before the pregnancy or early in the pregnancy. Follow-up of these patients proved these signs to be persistent. Subjects in both groups were used, as were a few non-pregnant nephritics from the Jersey City Medical Center. In almost all cases, the patients were antepartum and near term. Two of the pregnant nephritics were in their fourth and sixth months of gestation. Four urine specimens were collected by catheter, at hourly intervals. Midway in the test period blood was taken for a plasma creatinine determination.

The urine was centrifuged at 1500 r.p.m. for ten minutes and the clear supernatant fluid was used in all analyses.

Urinary protein. Duplicate samples of from 0.5 to $5 \mathrm{ml}$. of urine, depending upon the degree of proteinuria, were diluted to about $10 \mathrm{ml}$. in centrifuge tubes. Two ml. each of 10 per cent sodium tungstate and $2 / 3 \mathrm{~N}$ sulfuric acid were then added. After precipitating overnight, the protein was thrown down by centrifugation, the supernatant fluid decanted, and the protein redissolved in $1 \mathrm{ml}$. of 10 per cent sodium tungstate. After dilution to about $14 \mathrm{ml}$., $1 \mathrm{ml}$. of $2 / 3 \mathrm{~N}$ sulfuric acid was added. The following day the precipitates were again centrifuged down, dissolved in dilute sodium hydroxide, rinsed into N.P.N. tubes and digested with sulfuric acid and hydrogen peroxide; the solutions were nesslerized and read against nitrogen standards of comparable color. 
Plasma creatinine. The method of Folin and $\mathrm{Wu}(6)$ was used for the determination of plasma creatinine.

Urinary creatinine. Folin's method was used for urinary creatinine. All determinations were done in duplicate. Aliquots of urine were chosen which would give close colorimetric matches with the standard.

Calculations. The concentration of urine protein has been divided by the concentration ratio of plasma creatinine to urine creatinine. If the plasma clearance of endogenous creatinine measures the glomerular filtration (7) this computation gives the level of protein in the glomerular filtrate. If not quite all of the "apparent creatinine" of the plasma is creatinine, or if there is some tubular secretion of endogenous creatinine, the calculation gives a figure proportional to the protein content of the glomerular filtrate. If the secretion (if any) of creatinine does not vary with filtration, the calculated filtration of protein will vary independently of the actual protein leakage; i.e., the calculation of protein filtration by this means would not be valid. It will be assumed that the calculation is valid. The same assumption has been made for similar calculations by Bing (8) and by Berglund, Scriver and Medes (9) for exogenous creatinine which does appear to be partially secreted by the tubule cells (10). Whether the assumption be valid or not, results were obtained in specific toxemia differing from those found in Bright's disease.

\section{RESULTS AND DISCUSSION}

The reliability of the analytical methods was checked repeatedly by doing quadruplicate analyses of a urine for creatinine and protein. The lowest protein value was divided by the highest creatinine, and the highest protein by the lowest creatinine. From the results of this check, it was found that the average analytical error for the calculation of the "protein filtration" was about 5 per cent; in one instance the error was as high as 12 per cent.

To test the validity of the hypothesis that a diffuse renal lesion should result in a nearly constant leakage of protein, demonstrated by measurement of the protein filtration, a control series of non-pregnant nephritic patients has been studied.
TABLE I

Protein filtration in pregnant and non-pregnant nephritics, and in eclampsia and preeclamptic toxemia

\begin{tabular}{|c|c|c|c|}
\hline \multirow{2}{*}{ Diagnosis } & \multicolumn{2}{|c|}{$\begin{array}{l}\text { Protein in glo- } \\
\text { merular filtrate* }\end{array}$} & \multirow{2}{*}{$\underset{\substack{\text { mali } \\
\text { tion }}}{\operatorname{Maxi}-}$} \\
\hline & Lowest & Highest & \\
\hline & $\underset{\text { per }}{\operatorname{mgm} .}$ & $\underset{\text { per }}{\operatorname{mgm} .}$ & $\begin{array}{l}\text { per } \\
\text { cent }\end{array}$ \\
\hline \multicolumn{4}{|c|}{ NON-PREGNANT NEPHRITICS } \\
\hline $\begin{array}{l}\text { Chronic glomerulo-nephritis....... } \\
\text { Nephrotic syndrome............ } \\
\text { Chronic glomerulo-nephritis with } \\
\text { hypertensive encephalopathy.... } \\
\text { Ditto (same patient } 2 \text { weeks later).. } \\
\text { Chronic glomerulo-nephritis...... } \\
\text { Chronic glomerulo-nephritis....... }\end{array}$ & $\begin{array}{c}6.64 \\
9.95 \\
1.96 \\
31.5 \\
2.53 \\
0.144\end{array}$ & $\begin{array}{l}7.10 \\
11.71 \\
2.36 \\
38.9 \\
2.81 \\
0.153\end{array}$ & $\begin{array}{r}7 \\
18 \\
19 \\
24 \\
12 \\
6\end{array}$ \\
\hline
\end{tabular}

PREGNANT NEPHRITICS

\begin{tabular}{|c|c|c|c|}
\hline $\begin{array}{l}\text { Nephrotic syndrome } \ldots \ldots \ldots \ldots \\
\text { Chronic glomerulo-nephritis....... } \\
\text { Chronic glomerulo-nephritis....... } \\
\text { Chronic glomerulo-nephritis...... }\end{array}$ & $\begin{array}{r}15.60 \\
8.46 \\
7.98 \\
8.59\end{array}$ & $\begin{array}{r}18.50 \\
8.83 \\
9.20 \\
9.71\end{array}$ & $\begin{array}{r}18 \\
4 \\
15 \\
13\end{array}$ \\
\hline $\begin{array}{l}\text { Ditto (same patient } 5 \text { months } \\
\text { later) } \ldots \ldots \ldots \ldots \ldots \ldots \\
\text { Benign nephrosclerosis (?) } \ldots \ldots \ldots \ldots \\
\text { Ditto (same patient } 2 \text { weeks later) } \\
\text { Pyelonephritis } \ldots \ldots \ldots \ldots \ldots \ldots \ldots\end{array}$ & $\begin{array}{l}10.4 \\
3.16 \\
3.49 \\
0.93\end{array}$ & $\begin{array}{r}12.4 \\
3.59 \\
4.05 \\
1.00\end{array}$ & $\begin{array}{r}19 \\
13 \\
16 \\
8\end{array}$ \\
\hline
\end{tabular}

TOXEMIA OF PREGNANCY

\begin{tabular}{|c|c|c|c|}
\hline 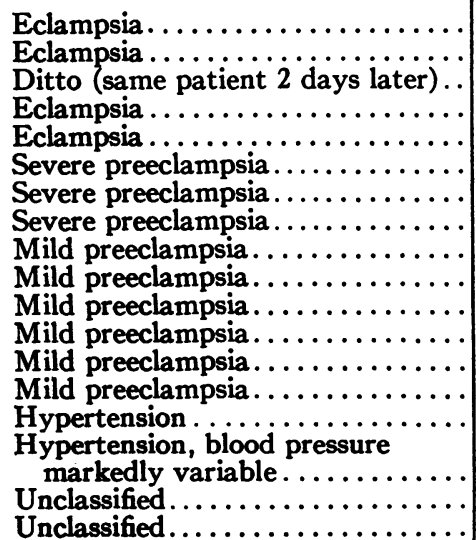 & \begin{tabular}{|r}
4.17 \\
2.22 \\
3.98 \\
0.27 \\
10.95 \\
1.05 \\
3.50 \\
1.56 \\
4.52 \\
1.10 \\
5.42 \\
2.37 \\
4.18 \\
6.40 \\
0.77 \\
0.09 \\
2.95 \\
1.65
\end{tabular} & $\begin{array}{r}5.52 \\
2.94 \\
5.96 \\
1.60 \\
14.40 \\
1.57 \\
5.60 \\
2.69 \\
5.73 \\
1.93 \\
8.16 \\
3.48 \\
7.45 \\
8.64 \\
1.04 \\
0.34 \\
.59 \\
2.40\end{array}$ & $\begin{array}{r}32 \\
32 \\
50 \\
492 \\
32 \\
50 \\
60 \\
73 \\
29 \\
76 \\
51 \\
47 \\
78 \\
35 \\
36 \\
303 \\
191 \\
45\end{array}$ \\
\hline
\end{tabular}

PREGNANT, MALIGNANT NEPHROSCLEROSIS

\begin{tabular}{l|r|r|r}
\hline Malignant nephrosclerosis ........ & 4.59 & 5.62 & 23 \\
Ditto (same patient 4 weeks later). & 5.72 & 6.37 & 11 \\
Ditto (same patient 10 days later). & 31.60 & 68.50 & 117 \\
\hline
\end{tabular}

* See text for qualifications and reservations.

As Table I shows, the variation in protein filtered from hour to hour is not very great. In 3 of the 5 cases it does not exceed the analytical error. 
The greatest variation occurred in a young boy with rapidly progressing chronic nephritis and hypertensive encephalopathy; in such a case vascular disturbances may well have been present.

This relative constancy of protein filtration in Bright's disease has been previously shown by Hanns (11) who found a parallelism between proteinuria and freezing-point depression in urine samples taken at intervals during the day. Bing (12) was perhaps the first to show the parallelism between creatinine excretion and protein excretion and to calculate the (approximate) concentration of protein in the glomerular filtrate. $\mathrm{He}$ found in renal disease only slight variation in the protein filtration over very short periods of time (8- to 12-minute intervals). Bing presents further confirmatory studies in a later publication (9), which also show a constancy in protein filtration from day to day.

The findings in 6 pregnant nephritics ( 8 determinations) are presented in Table I. As in nonpregnant nephritics the protein filtration was nearly the same from hour to hour. In one case the test was repeated after 2 weeks and in another case after 5 months (patients still pregnant). In both, the protein concentration in the glomerular filtrate had not changed much in the interval.

In contrast to the nearly constant protein filtration in each individual in the two groups of nephritics, there is marked variation from hour to hour among the eclamptic and preeclamptic patients. In one eclamptic the protein concentration in the glomerular filtrate varied from 0.27 to $1.60 \mathrm{mgm}$. per hundred $\mathrm{ml}$. (492 per cent variation). In one hypertensive toxemia patient with markedly labile blood pressure the protein filtration varied by 300 per cent. The least variation29 per cent-was found in a patient with mild preeclamptic toxemia. Most of the patients showed variations from 30 to 80 per cent, with a few running higher. The findings in 18 tests are summarized in Table I.

The fluctuating proteinuria, shown quantitatively by these studies, is a matter of common clinical observation. Many patients with toxemia of pregnancy show markedly variable urinary protein concentrations from morning to morning. While the level of diuresis accounts for much of this, it cannot explain a faint trace on one day, a
4 plus on the next, and perhaps a 1 plus on the third day.

Possibly the determination of the protein filtration, in successive hours, will prove to have some value in differentiating between so-called specific toxemia of pregnancy and Bright's disease in cases where the clinical diagnosis is equivocal. In the present study, care has been taken to select patients in whom the differential diagnosis could be made with some confidence. Further studies of doubtful cases, with diagnosis made by follow-up, are in progress. Quite probably some pregnant nephritics will also have toxemia of pregnancy; in such cases the proteinuria would be likely to fluctuate somewhat.

One case of rapidly progressing malignant nephrosclerosis was studied in the fourth month of pregnancy and after abortion (Table I). As the urea clearance fell from 32 per cent to 1.3 per cent, the concentration of protein in the glomerular filtrate increased greatly, from 4.59 to $68.5 \mathrm{mgm}$. per cent.

Finally, it might be emphasized that the proteinuria of eclampsia and preeclampsia is quite variable. This variability might be interpreted to mean that an important causative factor for the proteinuria is functional rather than anatomic. The functional changes are probably vascular spasms, as suggested in the introduction above. This was the hypothesis upon which this study was undertaken.

\section{SUMMARY AND CONCLUSIONS}

It is assumed that dividing the concentration of urinary protein by the ratio of urinary creatinine to plasma-endogenous creatinine will give the concentration of protein in the glomerular filtrate, or a value proportional to it.

Four urine specimens, collected at intervals of an hour, were taken from 6 pregnant and 5 nonpregnant nephritics, and from 4 eclamptic and 9 preeclamptic patients. The "protein filtration" was calculated and the variability from hour to hour was determined.

In nephritics, pregnant or not, the protein filtration shows very little variation from hour to hour.

In toxemia of pregnancy, the protein filtration is variable. It is suggested that this argues for a functional cause (vascular spasms) for the proteinuria. 
The writer is indebted to Drs. S. A. Cosgrove, J. F. Norton, and E. G. Waters for reading and criticizing the typescript, and for their permission to use patients from their services.

\section{BIBLIOGRAPHY}

1. Lever, J. C. W., Cases of puerperal convulsions with remarks. Guy's Hosp. Repts., 1842-1843, series 2, 1, 495.

2. Volhard, F., Nieren und Ableitende Harnwege. VI. Die Albuminurie. Handbuch der inneren Medizin, Julius Springer, Berlin, 1931, 6, part I, 813.

3. Irving, F. C., The vascular aspect of eclampsia. Am. J. Obst. \& Gynec., 1936, 31, 466.

4. Eastman, N. J., The vascular factor in toxemias of late pregnancy. Am. J. Obst. \& Gynec., 1937, 34, 549.

5. Chesley, L. C., Markowitz, I., and Wetchler, B. B., Proteinuria following momentary vascular constriction. J. Clin. Invest., 1939, 18, 51.
6. Peters, J. P., and Van Slyke, D. D., Quantitative Clinical Chemistry. Vol. II. Methods. Williams and Wilkins Co., Baltimore, 1932, pp. 602 and 604.

7. Miller, B. F., and Winkler, A. W., The renal excretion of endogenous creatinine in man; comparison with exogenous creatinine and inulin. J. Clin. Invest., 1938, 17, 31.

8. Bing, J., Studies on proteinuria. Levin and Munksgaard Ejnar Munksgaard, Copenhagen, 1936.

9. Berglund, H., Scriver, W. de M., and Medes, G., Proteinuria and plasma proteins. The Kidney in Health and Disease. Lea and Febiger, Philadelphia, 1935, pp. 508 to 515 .

10. Smith, H. W., The Physiology of the Kidney. Oxford University Press, New York, 1937.

11. Hanns, A., L'élimination de l'albumine dans la néphrite chronique. Presse Med., 1922, 30, 1110.

12. Bing, J., Unders $\phi$ gelser over albuminuriens mekanisme. Bibliot. f. Laeger, 1932, 124, 415. 